\title{
Effect of Gamma Irradiation Doses and Micro Elements on Some Physical, Chemical and Crop Parameters of Vigna sinensis L.
}

\author{
O. S. Hussein, O. I. Saleh and M. I. Abdullah
}

National Products Research Dept., National Centre for

Radiation Research and Technology (NCRRT), P. O. Box; 29

Nasr City, Egypt.

\begin{abstract}
7 HE present work aim to expose Vigna sinensis L. (cowpea) seeds to $\gamma$ - rays at dose levels 40,80 and 120Gy and to spray the growing plants with micro elements; boron (B) and zinc ( $\mathrm{Zn}$ ) after one month of planting; until harvest date, for increasing crop quality and quantity. Some physical parameters, some chemical analysis, the yield and net percentage of the produced crop were evaluated. The result obtained refer that, the 40Gy dose enhanced most of physical, chemical and yield parameters of cowpea crop. Moreover, the harvested crop was increased and improved in case of those produced from plants sprayed with different concentrations of B or Zn plus 40 Gy dose as compared with the other treatments used followed by the dose of $80 \mathrm{~Gy}$. Meanwhile, the dose of $120 \mathrm{~Gy}$ gave the least enhancement on the quality and quantity of the aforementioned treatments in cowpea crop.

Keyword: Vigna sinensis, $\gamma$-rays, physical, chemical, yield components.
\end{abstract}

Cowpea is one of important food legume crop in the tropical areas, particularly in Africa with an average of $24 \mathrm{~g}$ protein per $100 \mathrm{~g}$ and about $7 \mathrm{~g}$ lysine per $100 \mathrm{~g}$ protein (Joseph, 2006). Total carbohydrate content in cowpea. flour is $62.38 \mathrm{~g}$ $/ 100 \mathrm{~g}$, of starch alone accounts for $51.99 \mathrm{~g} / 100 \mathrm{~g}$ and because of their desirable physical and chemical properties, are known to be suitable for use as thickeners, extenders, stabilizers, gelling agents, dietary calories and texture modifiers in food formulations (Thomas and Atwell, 1997). Many metal ions are utilized in very small amounts as essential nutrients. Both low and excess amounts of micronutrients can suppress growth, cell cycle, development, and survival. As a micronutrient, $\mathrm{Zn}$ is required in a large number of enzymes and plays an essential role in DNA transcription. A typical symptom of $\mathrm{Zn}$ deficiency is the stunted growth of leaves, commonly known as "little leaf" and is caused by the 
oxidative degradation of the growth hormone auxin (Paarbhu and Muthuchelian, 2011). Also, B is one of the essential trace elements (Marschner, 1995). It has been purposed that $\mathrm{B}$ is involved in many plant metabolisms (Lukaszewski and Blevins, 1996). A limited amount of B is necessary for the normal development of plants; however, a high level of B in soil is generally toxic. B is considered to be involved in nucleic acid metabolism, carbohydrate and protein metabolism, indole acetic acid metabolism, cell wall synthesis, cell wall structure, membrane integrity and function, and phenol metabolism; however, molecular basis of these roles is mostly unknown (Loomis and Durst,1992, Marschner, 1995 and Goldbach et al., 2001).

Gamma irradiation has been used in the biological studies from low doses stimulation to high-doses inhibition (Ribeiro and Machado, 2007). The relatively low doses ionizing radiation on plants as well as in vitro studies are manifested as accelerated cell proliferation, cell growth, enzyme activity, stress resistance and mutation induction (Chakravarty and Sen, 2001).

This work aims to study the effect of gamma rays and certain microelements for increasing cowpea plants, growth, quality and productivity.

\section{Material and Methods}

A cowpea cultivar, Kafr El Sheikh was obtained from Horticulture Research Institute, Agriculture Research Centre, Dokki, Giza, Egypt. Cowpea seeds irradiated at dose levels of (40,80 and 120 Gy) at NCRRT, Nasr City, Cairo, Egypt. Irradiation facility used was Indian Gamma Cell Research Irradiator $\left({ }^{60} \mathrm{Co}\right)$; the dose rate was $1.8 \mathrm{~Gy} / \mathrm{Sec}$. At time of experiment, irradiated and un-irradiated seeds were planted at depth $2-5 \mathrm{~cm}$ with space 30 $\mathrm{cm}$, and four replicate from each treatment in complete randomize blocks were cultivated in a wire house at NCRRT. The soil used for cultivation was clayloamy soil with $\mathrm{pH} 7.7$, after one month from planting date, plants were sprayed by microelements, of $\mathrm{Zn}(200$ and $300 \mathrm{ppm} / \mathrm{L}$ ) and B (50 and 100ppm/ L), monthly till harvest date. The treated cowpea seeds samples, from control, 40, 80 and 120Gy; control $\mathrm{Zn}_{1}(200 \mathrm{ppm}), 40 \mathrm{~Gy} \mathrm{Zn}_{1}$, 80Gy $\mathrm{Zn}_{1}, 120 \mathrm{~Gy} \mathrm{Zn}_{1}$; control $\mathrm{Zn}_{2}$ (300ppm), 40Gy $\mathrm{Zn}_{2}$, 80Gy Zn $\mathrm{Zn}_{2}$, 120Gy Zn $\mathrm{Zn}_{2}$; control $\mathrm{B}_{1}(50 \mathrm{ppm}), 40 \mathrm{~Gy} \mathrm{~B}{ }_{1}$, $80 \mathrm{~Gy} \mathrm{~B}_{1} ; 120 \mathrm{~Gy} \mathrm{~B}_{1}$ and control $\mathrm{B}_{2}(100 \mathrm{ppm}), 40 \mathrm{~Gy} \mathrm{~B} \mathrm{~B}_{2}, 80 \mathrm{~Gy} \mathrm{~B} \mathrm{~B}_{2}, 120 \mathrm{~Gy} \mathrm{~B}_{2}$ were collected and dried in an oven at $60^{\circ} \mathrm{C}$ for $48 \mathrm{~h}$, then milled to fine powder

Egypt. J. Rad. Sci. Applic., Vol. 24, No. 1 (2011) 
foe evaluation certain physical parameters, yield components of the plants and moreover, estimation of some chemical characters in harvested seeds of cowpea.

\section{Physical parameters measurements}

Plant height $(\mathrm{cm})$, leaf number, branch number, root length $(\mathrm{cm})$, plant fresh \& dry wt $(\mathrm{g})$, horn \& seeds number and wt $(\mathrm{g})$ of cowpea were measured from untreated and treated plants with both of $\gamma$-rays doses and some micro elements concentrations as the mentioned before.

\section{Cowpea crop parameters}

Cowpea seeds productivity under the investigation was estimated by recording horn \& seed wt/100 horn and wt of 100 seed. Also, the number and horn $\&$ seed wt/Fadden, in addition to the shelling percentage which recorded as follows:

Shelling $\%=$ Seed wt of the horns/ Horn wt $\times 100$.

\section{Chemical determination}

\section{Elements}

Samples digested completely by wet method using concentrated sulfuric acid in presence of percholoric acid, then diluted and measured. $\mathrm{K}$ and Na were estimated by inductively coupled plasma-Atomic Emission Spectrometer (ICPAES, England). Mg, Ca, Zn, B and P determined according to AOAC (1995) by using Atomic Absorption Spectrometer (SOLAR- UNICAM 989, England).

\section{Total protein}

Total protein calculated by multiplying the total nitrogen by 6.25 . The total nitrogen was determined by kjeldahl method (AOAC, 1984).

\section{Carbohydrates}

Total soluble sugars extracted by recommended method of Shannon (1968) and determined by method of Smith et al. (1956). Moreover, reducing sugars determined by method of Hosfield et al. (1982).

\section{Fatty acids}

The method of AOAC (2000) was conducted for lipid extraction from sample using chloroform: methanol $(2: 1 \mathrm{v} / \mathrm{v})$. The lipid samples were saponified over night with ethanolic $\mathrm{KOH}(20 \%)$ at room temperature according to Vogel (1975). The methyl esters of fatty acids obtained from oil of samples and 
standard materials were analyzed at NCRRT with Pye Unicam Series 304 gas chromatography equipped with dual flam ionization detector and dual channel recorder. The separation of fatty acid methyl esters was conducted using a coiled glass column (1.5mx 4mm) packed with Diatomite (100-120 mesh) and coated with $10 \%$ polyethylene glycol adipate (PEGA) The column oven temperature was programmed at $8^{\circ} \mathrm{C} / \mathrm{min}$ from 70 to $190^{\circ} \mathrm{C}$, then isothermally at $190^{\circ} \mathrm{C}$ for $25 \mathrm{~mm}$ with nitrogen at $30 \mathrm{ml} / \mathrm{min}$. The unsaponifiables were also fractionated on a coiled glass column (2.8m x $4 \mathrm{~mm})$ packed with Diatomite (100-120 mesh) and coated with $3 \% \mathrm{OV}-17$. The oven temperature was programmed at $10^{\circ} \mathrm{C} / \mathrm{min}$ from $70^{\circ} \mathrm{C}$, then isothermally at $270^{\circ} \mathrm{C}$ for $25 \mathrm{~mm}$ and nitrogen flow rate was $30 \mathrm{~m} 1 /$ min. Detector, injector temperatures and hydrogen, air flow rates were generally $300^{\circ} \mathrm{C}, 280^{\circ} \mathrm{C}$ and $33 \mathrm{ml}, 330 \mathrm{ml} / \mathrm{mm}$, respectively (PU 4810, Philips).

\section{Statistical analysis}

Data obtained were statistically analyzed by using Costat statistical program software (1990) and Duncan's multiple range test (Duncan, 1955) was applied at $5 \%$ probability level to compare the differences among estimated parameters.

\section{Results and Discussion}

\section{Effect of $\gamma$-rays and some microelements on physical parameters}

Perusal to the effect of $\gamma$-rays and micro elements on physical parameters of cowpea measured and illustrated in Table 1 . The results obtained refer that, all treatments used either $\gamma$-rays or spraying with micronutrients enhanced vigor in several aspects including plant height, leafiness, root and branch development, fresh and dry wt both in total plants and in seeds. Many investigators are in agreeing with result obtained (Ali et al., 1996, Chakravarty and Sen, 2001 and Mahmoud et al., 2009). Aziz et al. (2010) observed that plant growth parameters of Cymbopogon citrates significantly increased by $\mathrm{Zn}$ application and reported that 200ppm resulted in a great increase in plant height, fresh and dry wt yield.

Also, Kassem et al. (2011) found that agrochemicals foliar sprays $\left(2,4-\mathrm{D}^{+}\right.$ boric acid) at pea or marble stages significantly increased fruit wt in two season $(2003,2004)$. It was observed that, the best quality and quantity of cowpea were obtained, when plants sprayed by 50ppm concentration of B and produced from seeds irradiated by $120 \mathrm{~Gy}$, or untreated control. It must be mentioned her that Egypt. J. Rad. Sci. Applic., Vol. 24, No. 1 (2011) 
the heaviest horn dry wt was obtained from plants produced from seeds treated by 40 Gy Zn1. Similar results on plant growth were obtained by Orabi (1998), Ribeiro and Machado (2007) and Hussein (2008) upon exposing seeds to different doses of $\gamma$-rays, all growth parameters (shoot length, number of pods/ plant, number of seeds/ plant and their wt) increased above control.

TABLE 1. Effect of $\gamma$-rays and microelements on physical parameters in $V$. Sinensis.

\begin{tabular}{|c|c|c|c|c|c|c|c|c|}
\hline Dose/Gy & $\begin{array}{c}\text { Plant } \\
\text { height } \\
\mathrm{cm}\end{array}$ & $\begin{array}{l}\text { Leaf } \\
\text { No. }\end{array}$ & $\begin{array}{c}\text { Root } \\
\text { length } \\
\mathrm{cm}\end{array}$ & $\begin{array}{c}\text { Branch } \\
\text { No. }\end{array}$ & $\begin{array}{c}\text { Plant } \\
\text { fresh wt } \\
\mathrm{g}\end{array}$ & $\begin{array}{c}\text { Plant } \\
\text { dry wt } \\
\text { g }\end{array}$ & $\begin{array}{c}\text { Horn } \\
\text { No. }\end{array}$ & $\begin{array}{c}\text { Horn } \\
\text { dry wt } \\
\text { g }\end{array}$ \\
\hline Con & $32.1^{\mathrm{c}}$ & $14.8^{\mathrm{e}}$ & $14.6^{\mathrm{cde}}$ & $3^{\mathrm{f}}$ & $62.9^{f}$ & $17.68^{\mathrm{g}}$ & $18.5^{\mathrm{efg}}$ & $19.7^{\text {bc }}$ \\
\hline 40 & $31.7^{\mathrm{c}}$ & $35.1^{\text {bcde }}$ & $19^{\mathrm{bc}}$ & $5.2^{\text {bcdef }}$ & $374.6^{b}$ & $56.95^{\mathrm{c}}$ & $36.8^{\mathrm{abc}}$ & $21.1^{\mathrm{ab}}$ \\
\hline 80 & $42.8^{\mathrm{c}}$ & $40.5^{\mathrm{abc}}$ & $16.8^{\mathrm{bc}}$ & $5.65^{\text {bcde }}$ & $305^{\text {bcd }}$ & $48.6^{\text {cd }}$ & $28.5^{\text {bcde }}$ & $23.8^{\mathrm{ab}}$ \\
\hline 120 & $70^{b}$ & $41^{\mathrm{abc}}$ & $19.5^{\mathrm{b}}$ & $8.5^{\mathrm{a}}$ & $220.2^{\text {cde }}$ & $42.4^{\text {cdef }}$ & $22.3^{\text {def }}$ & $14.9^{\mathrm{fg}}$ \\
\hline Con $\mathrm{Zn}_{1}$ & $82.6^{\mathrm{a}}$ & $38.8^{\text {bcde }}$ & $19.5^{\mathrm{b}}$ & $4^{\text {def }}$ & $290^{\text {bcde }}$ & $50.03^{\mathrm{cd}}$ & $33.5^{\text {abcd }}$ & $16.7^{\mathrm{fg}}$ \\
\hline $40 \mathrm{Zn}_{1}$ & $35^{\mathrm{c}}$ & $36^{\text {bcde }}$ & $19.5^{\mathrm{b}}$ & $4^{\text {def }}$ & $289.2^{\text {bcde }}$ & $42.9^{\text {cdef }}$ & $21^{\mathrm{et}}$ & $27.7^{\mathrm{ab}}$ \\
\hline $80 \mathrm{Zn}_{1}$ & $37^{\mathrm{c}}$ & $38.5^{\text {bcde }}$ & $11.5^{\mathrm{ef}}$ & $5.75^{\text {bcde }}$ & $198.5^{\text {cde }}$ & $33.9^{\text {defg }}$ & $20.8^{\text {ef }}$ & $13.3^{\mathrm{de}}$ \\
\hline $120 \mathrm{Zn}_{1}$ & $36^{\mathrm{c}}$ & $32^{\text {bcde }}$ & $15.3^{\text {bcde }}$ & $7.25^{\mathrm{ab}}$ & $312.9^{\mathrm{bc}}$ & $49^{\mathrm{cd}}$ & $38.3^{\mathrm{ab}}$ & $15.2^{\mathrm{fg}}$ \\
\hline Con $\mathrm{Zn}_{2}$ & $35.3^{\mathrm{c}}$ & $27^{\text {cde }}$ & $16.4^{\mathrm{bcd}}$ & $6.25^{\mathrm{bcd}}$ & $197.3^{\text {cde }}$ & $32.9^{\operatorname{detg}}$ & $20.5^{\mathrm{ef}}$ & $12.9^{g}$ \\
\hline $40 \mathrm{Zn}_{2}$ & $31^{\mathrm{c}}$ & $39^{\mathrm{abcd}}$ & $19.5^{\mathrm{b}}$ & $6^{\text {bcd }}$ & $273.3^{\text {bcde }}$ & $48.5^{\mathrm{cd}}$ & $25^{\text {cdef }}$ & $13.7^{\mathrm{fg}}$ \\
\hline $80 \mathrm{Zn}_{2}$ & $42.3^{\mathrm{c}}$ & $28.8^{\mathrm{cde}}$ & $12.3^{\text {def }}$ & $7^{\mathrm{abc}}$ & $155.7^{\mathrm{ef}}$ & $22.7^{\mathrm{g}}$ & $15.3^{\mathrm{fg}}$ & $13.2^{\mathrm{de}}$ \\
\hline $120 \mathrm{Zn}_{2}$ & $32.8^{\mathrm{c}}$ & $21^{\mathrm{de}}$ & $9.5^{\mathrm{f}}$ & $8.75^{\mathrm{a}}$ & $168.1^{\mathrm{def}}$ & $23.9^{\mathrm{g}}$ & $15.5^{\mathrm{tg}}$ & $17.2^{\mathrm{fg}}$ \\
\hline Con. $B_{1}$ & $35.8^{\mathrm{c}}$ & $32.3^{\text {abcde }}$ & $16^{\mathrm{bcd}}$ & $5.3^{\text {bcdef }}$ & $566^{a}$ & $94.6^{\mathrm{a}}$ & $43.3^{\mathrm{a}}$ & $23.5^{\mathrm{ab}}$ \\
\hline $40 B_{1}$ & $22.3^{\mathrm{c}}$ & $26.5^{\text {cde }}$ & $24.5^{\mathrm{a}}$ & $6.25^{\mathrm{bcd}}$ & $259.5^{\text {bcde }}$ & $51.9^{\mathrm{c}}$ & $38^{\mathrm{ab}}$ & $21.5^{\mathrm{ab}}$ \\
\hline $80 B_{1}$ & $27.5^{\mathrm{c}}$ & $50.3^{\mathrm{a}}$ & $17^{\mathrm{bc}}$ & $5^{\text {bcdef }}$ & $211.5^{\text {cde }}$ & $95.9^{\mathrm{a}}$ & $35.8^{\mathrm{abc}}$ & $19.4^{\mathrm{ef}}$ \\
\hline $120 B_{1}$ & $36.5^{\mathrm{c}}$ & $37^{\mathrm{abcd}}$ & $25.5^{\mathrm{a}}$ & $4^{\text {def }}$ & $387.1^{b}$ & $74.7^{\mathrm{b}}$ & $43.3^{\mathrm{a}}$ & $19.1^{\mathrm{ef}}$ \\
\hline Con $B_{2}$ & $39.8^{\mathrm{c}}$ & $37^{\mathrm{abcd}}$ & $25.5^{\mathrm{a}}$ & $4^{\text {def }}$ & $227.2^{\text {cde }}$ & $43.8^{\text {cdef }}$ & $17.3^{\text {efg }}$ & $26.9^{\mathrm{a}}$ \\
\hline $40 \mathrm{~B}_{2}$ & $47.4^{\mathrm{c}}$ & $25^{\text {cde }}$ & $19.3^{b}$ & $4.25^{\mathrm{def}}$ & $202.3^{\text {cde }}$ & $29^{\mathrm{efg}}$ & $8^{g}$ & $18.8^{\mathrm{efg}}$ \\
\hline $80 \mathrm{~B}_{2}$ & $37^{\mathrm{c}}$ & $47^{\text {ab }}$ & $15.3^{\text {bcde }}$ & $4.75^{\text {cdef }}$ & $326.9^{\mathrm{bc}}$ & $45.3^{\text {cde }}$ & $25.8^{\text {cdef }}$ & $15.7^{\mathrm{fg}}$ \\
\hline $120 \mathrm{~B}_{2}$ & $31.5^{\mathrm{c}}$ & $34.3^{\text {bcde }}$ & $15.3^{\text {bcde }}$ & $3.5^{\mathrm{ef}}$ & $198.1^{\text {cde }}$ & $27.2^{\mathrm{fg}}$ & $23^{\text {def }}$ & $15.5^{\mathrm{cd}}$ \\
\hline L.S.D. & 22.5 & 15.3 & 3.77 & 1.99 & 114.9 & 15.19 & 10.5 & 5.19 \\
\hline
\end{tabular}

Con: control. $\quad \mathrm{Zn}_{1}: 200 \mathrm{ppm} . \quad \mathrm{Zn}_{2}: 300 \mathrm{ppm} . \quad \mathrm{B}_{1}: 50 \mathrm{ppm} . \quad \mathrm{B}_{2}: 100 \mathrm{ppm}$

Hassan et al. (2000) examined the effect of 20, 40, 60 and 80Gy gamma irradiation doses on growth of cowpea. Irradiation treatments caused decrease in shoot dry wt with the increase of gamma dose. On the other hand, Nassar et al. (2004) found that gamma irradiation enhanced plant height and shoot. Abdul Majeed et al. (2010) reported that the growth parameters showed declining tendency with increasing doses of gamma irradiation. 


\section{Effect of $\gamma$-rays and some micro-elements on chemical parameters Elements components}

When cowpea plants treated by $\mathrm{Zn}_{1}, \mathrm{Zn}_{2}, \mathrm{~B}_{1}$ and $\mathrm{B}_{2}$, it was noticed that $\mathrm{P}$ and $\mathrm{Ca}$ values were close to normal seeds with some exception. The harvested cowpea seeds irradiated as seeds before planting contain $\mathrm{P}$ increasing in seed samples treated with $40 \mathrm{~Gy}$ and Ca increased at 40 and 120 .

TABLE 2. Elements (mg/g) in $V$. Sinensis as affected by $\gamma$-rays and microelements.

\begin{tabular}{|c|c|c|c|c|c|c|c|}
\hline \multirow{2}{*}{ Dose/Gy } & \multicolumn{7}{|c|}{ Concentration elements mg/g dry wt } \\
\hline & $\mathbf{P}$ & $\mathbf{N a}$ & $\mathbf{K}$ & B & $\mathbf{Z n}$ & $\mathbf{C a}$ & Mg \\
\hline Con & 0.0706 & $1.504 \times 10^{-7}$ & $1.158 \times 10^{-4}$ & $2.766 \times 10^{-4}$ & 0.06 & 0.676 & 0.972 \\
\hline 40 & 0.1088 & $1.503 \times 10^{-7}$ & $9.769 \times 10^{-5}$ & $2.765 \times 10^{-4}$ & 0.04 & 0.74 & 0.349 \\
\hline 80 & 0.0669 & $1.439 \times 10^{-7}$ & $9.939 \times 10^{-5}$ & $2.763 \times 10^{-4}$ & 0.013 & 0.692 & 0.38 \\
\hline 120 & 0.0395 & $1.545 \times 10^{-7}$ & $1.020 \times 10^{-4}$ & $2.761 \times 10^{-4}$ & 0.037 & 0.913 & 0.726 \\
\hline Con $\mathrm{Zn}_{1}$ & 0.0646 & $1.421 \times 10^{-7}$ & $1.045 \times 10^{-4}$ & $2.765 \times 10^{-4}$ & 0.035 & 0.49 & 0.349 \\
\hline $40 \mathrm{Zn}_{1}$ & 0.0741 & $1.430 \times 10^{-7}$ & $1.017 \times 10^{-4}$ & $2.759 \times 10^{-4}$ & 0.029 & 0.931 & 0.325 \\
\hline $80 \mathrm{Zn}_{1}$ & 0.0085 & $1.432 \times 10^{-7}$ & $8.919 \times 10^{-5}$ & $2.761 \times 10^{-4}$ & 0.011 & 0.552 & 0.313 \\
\hline $120 \mathrm{Zn}_{1}$ & 0.0729 & $1.459 \times 10^{-7}$ & $1.066 \times 10^{-4}$ & $2.754 \times 10^{-4}$ & 0.018 & 0.904 & 0.328 \\
\hline $\operatorname{Con} \mathrm{Zn}_{2}$ & 0.0515 & $1.441 \times 10^{-7}$ & $9.989 \times 10^{-5}$ & $2.765 \times 10^{-4}$ & 0.017 & 0.648 & 0.358 \\
\hline $40 \mathrm{Zn}_{2}$ & 0.0765 & $1.376 \times 10^{-7}$ & $1.088 \times 10^{-4}$ & $2.759 \times 10^{-4}$ & 0.027 & 0.712 & 0.353 \\
\hline $80 \mathrm{Zn}_{2}$ & 0.0777 & $1.339 \times 10^{-7}$ & $1.004 \times 10^{-4}$ & $2.762 \times 10^{-4}$ & 0.007 & 0.776 & 0.429 \\
\hline $120 \mathrm{Zn}_{2}$ & 0.0801 & $1.414 \times 10^{-7}$ & $1.070 \times 10^{-4}$ & $2.765 \times 10^{-4}$ & 0.022 & 0.473 & 0.324 \\
\hline Con. $B_{1}$ & 0.0753 & $1.405 \times 10^{-7}$ & $1.032 \times 10^{-4}$ & $2.760 \times 10^{-4}$ & 0.008 & 0.853 & 0.303 \\
\hline $40 B_{1}$ & 0.0825 & $1.373 \times 10^{-7}$ & $1.106 \times 10^{-4}$ & $2.763 \times 10^{-4}$ & 0 & 0.547 & 0.373 \\
\hline $80 B_{1}$ & 0.0861 & $1.431 \times 10^{-7}$ & $1.059 \times 10^{-4}$ & $2.760 \times 10^{-4}$ & 0.008 & 0.506 & 0.306 \\
\hline $120 B_{1}$ & 0.0598 & $1.370 \times 10^{-1}$ & $1.020 \times 10^{-4}$ & $2.765 \times 10^{-4}$ & 0.009 & 0.47 & 0.415 \\
\hline Con $B_{2}$ & \begin{tabular}{|l|}
0.092 \\
\end{tabular} & $1.478 \times 10^{-7}$ & $1.058 \times 10^{-4}$ & $2.761 \times 10^{-4}$ & 0.008 & 0.547 & 0.315 \\
\hline $40 B_{2}$ & 0.0896 & $1.460 \times 10^{-7}$ & $1.126 \times 10^{-4}$ & $2.762 \times 10^{-4}$ & 0.004 & 0.541 & 0.306 \\
\hline $80 \mathrm{~B}_{2}$ & 0.1052 & $1.349 \times 10^{-7}$ & $1.041 \times 10^{-4}$ & $2.759 \times 10^{-4}$ & 0.07 & 0.724 & 0.303 \\
\hline $120 \mathrm{~B}_{2}$ & 0.0813 & $1.346 \times 10^{-7}$ & $9.889 \times 10^{-5}$ & $2.760 \times 10^{-4}$ & 0.001 & 0.485 & 0.288 \\
\hline
\end{tabular}

Ca concentration increased especially in the control group, and in $\mathrm{Zn}_{1}$ and $\mathrm{Zn}_{2}$, except $120 \mathrm{~Gy} \mathrm{Zn}_{2}$. While $\mathrm{B}_{1}$ and $\mathrm{B}_{2}$ treatments decrease its concentration. Phosphorus had similar trend as in $\mathrm{Ca}$, where its concentrations in $\mathrm{Zn}_{1}$ and $\mathrm{Zn}_{2}$ increased and decreased in $\mathrm{B}_{1}$ and $\mathrm{B}_{2}$ except the $120 \mathrm{~B}_{1}, 40 \mathrm{~B}_{2}$ and $120 \mathrm{~B}_{2}$ specimens Table 2. Panjie and Jegadees (1959) think that the simulative effect of $\gamma$-rays on $\mathrm{P}$ absorption may be due to an interactive of these $\gamma$-rays with hormonal biosynthesis. The increase in the absorption of $\mathrm{NO}_{3}, \mathrm{~K}$ and $\mathrm{P}$ were stimulated by application of $\gamma$-rays. This increase might be due to the effect of Egypt. J. Rad. Sci. Applic., Vol. 24, No. 1 (2011) 
such $\gamma$-rays on accelerating the transpiration rate through increasing the stomata aperture. Regarding to sodium, no tangible change noticed in their concentrations absorbed by cowpea plants affected by $\gamma$-rays, microelement and interaction between both of them where their values ranged between $\left(1.4 \times 10^{-7}\right.$ to $1.5 \times 10^{-7} \mathrm{mg} / \mathrm{g}$ dry wt). As a result of aforementioned treatments, $\mathrm{K}$ concentration was increased. The harvested seeds contain $1.16 \times 10^{-4} \mathrm{mg} / \mathrm{g}$ dry wt changed in those produced from plants sprayed with $\mathrm{Zn}_{1}, \mathrm{Zn}_{2}, \mathrm{~B}_{1}$ or $\mathrm{B}_{2}$ to $1.03 \times 10^{-4}, 1.05 \times 10^{-4}, 1.06 \times 10^{-4}$, and $9.989 \times 10^{-5} \mathrm{mg} / \mathrm{g}$ dry wt. Also, a little increase in seeds that harvested from plants sprayed by microelements with some exception observed. B behaves the same trends like K. Moreover, all treatments applied decreased $\mathrm{Mg}$ concentration in seeds (treated or untreated) that produced from plants sprayed by microelements or not sprayed. The results obtained refer to $80 \mathrm{Zn}_{2}$, and $\mathrm{B}_{2}$ group that gained high $\mathrm{Mg}$ concentration when compared by its corresponding control. We must refer to group of plants that sprayed by $\mathrm{B}_{1}$ where it gained high $\mathrm{Mg}$ concentration than its corresponding control (0.303), in addition to $80 \mathrm{Zn}_{2}$, but all of them still less than main control.

\section{Total nitrogen and total protein}

It was noticed that total nitrogen percentage in harvested cowpea seeds were $2.048 \%$. But, $\mathrm{N} \%$ increase with the increase in radiation dose, or spraying by microelements or their interaction. Also, the same trends were obtained in total protein in cowpea seeds. Where, the total protein content increased with the increase in dose of radiation, especially at dose of 40 Gy that increased its content to $(21.656 \mathrm{~g} / 100 \mathrm{~g}$ dry wt) as compared by the control $(15.505 \mathrm{~g} / 100 \mathrm{~g}$ dry wt). Also, the highest increase in total proteins observed when seeds irradiated with $40 \mathrm{~Gy}$ and sprayed by microelements of $\mathrm{B}_{1}, \mathrm{~B}_{2}, \mathrm{Zn}_{2}$ and $\mathrm{Zn}_{1}$ after planting. Their values were $25.069,24.5,22.313$ and $21.07 \mathrm{~g} / 100 \mathrm{~g}$ dry wt respectively, Table 3. Similar findings were obtained on Lupine and cowpea (Khodary, 2004 and Vasconcelos et al., 2010).

Abou El-Yazied (2011) refer that yield per Fadden was significantly correlated with total protein percent. Changes in protein fractions may be related to some cross linking or aggregation of proteins as a result of gamma irradiation which could affect nitrogen solubility (Ciesta et al., 2000).

Egypt. J. Rad. Sci. Applic., Vol. 24, No. 1 (2011) 


\section{Total carbohydrate and reducing sugars}

The foliar treatments by micronutrients considered an effective treatment for increasing total carbohydrates in harvested crop of cowpea. As showed in Table 3. It was noticed that, growing control plants sprayed with $B_{2}$ and $B_{1}$ have the maximum carbohydrates values $(77.2$ and $74.0 \mathrm{~g} / 100 \mathrm{~g}$ dry wt) as well as the treatment of $40 \mathrm{~Gy} \mathrm{Zn}_{1}(77.1 \mathrm{~g} / 100 \mathrm{~g}$ dry wt) comparing with normal seeds $\left(59.9 \mathrm{~g} / 100 \mathrm{~g}\right.$ dry wt). On the contrary, treatments of $80 \mathrm{~Gy} \mathrm{~B}_{1}, 80 \mathrm{~Gy} \mathrm{~B} \mathrm{~B}_{2}, 120 \mathrm{~Gy}$ $\mathrm{B}_{1}$ and $120 \mathrm{~Gy} \mathrm{~B}_{2}$ had the total carbohydrates values less than the normal seeds, to reach 41.1, 41.4, 40.5 and 39g/ 100g dry wt, respectively. Abou El-Yazied (2011) refer that yield per Fadden was significantly correlated with total sugars.

TABLE 3. Total Nitrogen, protein and carbohydrates g/ $100 \mathrm{~g}$ dry wt in $V$. Sinensis shoots as affected by $\gamma$-rays and micro-element treatments.

\begin{tabular}{|c|c|c|c|c|}
\hline Dose/Gy & $\begin{array}{c}\text { Total } \\
\text { nitrogen }\end{array}$ & $\begin{array}{c}\text { Total } \\
\text { proteins }\end{array}$ & $\begin{array}{c}\text { Total } \\
\text { carbohydrates }\end{array}$ & $\begin{array}{c}\text { Reducing } \\
\text { sugar }\end{array}$ \\
\hline Con & $2.481^{\mathrm{b}}$ & $15.505^{b}$ & $59.9^{\text {ef }}$ & $11.7^{\mathrm{cde}}$ \\
\hline 40 & $3.465^{\mathrm{a}}$ & $21.656^{\mathrm{a}}$ & $69.2^{b}$ & $17.1^{\mathrm{a}}$ \\
\hline 80 & $3.136^{\mathrm{a}}$ & $19.6^{\mathrm{a}}$ & $64.1^{\text {cde }}$ & $13.5^{b c}$ \\
\hline 120 & $3.237^{\mathrm{a}}$ & $20.23^{\mathrm{a}}$ & $53.6^{\text {gh }}$ & $10.4^{\mathrm{efg}}$ \\
\hline Con $\mathrm{Zn}_{1}$ & $3.297^{\mathrm{a}}$ & $20.606^{a}$ & $67.4^{b c}$ & $14.4^{b}$ \\
\hline $40 \mathrm{Zn}_{1}$ & $3.371^{\mathrm{a}}$ & $21.07^{\mathrm{a}}$ & $77.1^{a}$ & $13.2^{b c d}$ \\
\hline $80 \mathrm{Zn}_{1}$ & $3.157^{\mathrm{a}}$ & $19.731^{\mathrm{a}}$ & $60.6^{\mathrm{def}}$ & $11.3^{\mathrm{de}}$ \\
\hline $120 \mathrm{Zn}_{1}$ & $3.332^{\mathrm{a}}$ & $20.825^{a}$ & $57.5^{\mathrm{fg}}$ & $8.7^{\text {fgh }}$ \\
\hline Con $\mathrm{Zn}_{2}$ & $3.396^{\mathrm{ab}}$ & $21.227^{\mathrm{ab}}$ & $64^{\text {cde }}$ & $13.4^{b c}$ \\
\hline $40 \mathrm{Zn}_{2}$ & $3.57^{\mathrm{a}}$ & $22.313^{\mathrm{a}}$ & $49.6^{\text {hi }}$ & $12^{\mathrm{cde}}$ \\
\hline $80 \mathrm{Zn}_{2}$ & $2.786^{\mathrm{a}}$ & $17.413^{a}$ & $47.8^{i}$ & $11.2^{\mathrm{e}}$ \\
\hline $120 \mathrm{Zn}_{2}$ & $3.427^{\mathrm{ab}}$ & $21.42^{\mathrm{ab}}$ & $40.7^{j}$ & $9.9^{\mathrm{efg}}$ \\
\hline Con. $B_{1}$ & $3.648^{\mathrm{ab}}$ & $22.803^{\mathrm{ab}}$ & $74.0^{\mathrm{a}}$ & $14.8^{b}$ \\
\hline $40 B_{1}$ & $4.01^{\mathrm{a}}$ & $25.069^{a}$ & $65.5^{\text {bcd }}$ & $10.4^{\text {efg }}$ \\
\hline $80 B_{1}$ & $3.659^{\mathrm{ab}}$ & $22.867^{\mathrm{ab}}$ & $41.1^{j}$ & $11.1^{\mathrm{e}}$ \\
\hline $120 \mathrm{~B}_{1}$ & $3.22^{b}$ & $20.125^{b}$ & $41.5^{j}$ & $15.0^{\text {gh }}$ \\
\hline $\operatorname{Con} B_{2}$ & $3.528^{\mathrm{a}}$ & $22.05^{\mathrm{a}}$ & $77.2^{a}$ & $10.5^{b}$ \\
\hline $40 B_{2}$ & $3.92^{\mathrm{a}}$ & $24.5^{\mathrm{a}}$ & $61.6^{\text {def }}$ & $8.4^{\text {ef }}$ \\
\hline $80 \mathrm{~B}_{2}$ & $3.388^{\mathrm{a}}$ & $21.175^{\mathrm{a}}$ & $40.5^{j}$ & $7.7^{h}$ \\
\hline $120 B_{2}$ & $3.423^{\mathrm{a}}$ & $21.394^{\mathrm{a}}$ & $39.0^{j}$ & $7.6^{h}$ \\
\hline L.S.D ${ }_{0.05}$ & 0.6369 & 0.6369 & 4.674 & 1.756 \\
\hline
\end{tabular}

Con: control. $\quad \mathrm{Zn}_{1}: 200 \mathrm{ppm} . \quad \mathrm{Zn}_{2}: 300 \mathrm{ppm} . \mathrm{B}_{1}: 50 \mathrm{ppm} . \mathrm{B}_{2}: 100 \mathrm{ppm}$.

The reducing sugars value of normal seeds was $11.7 \mathrm{~g} / 100 \mathrm{~g}$ dry wt as in Table 3 as well as the treatments of $40 \mathrm{~Gy} \mathrm{Zn}_{2}, 80 \mathrm{~Gy} \mathrm{Zn}_{1}, 80 \mathrm{~Gy} \mathrm{Zn}_{2}$ and $80 \mathrm{~Gy}$

Egypt. J. Rad. Sci. Applic., Vol. 24, No. 1 (2011) 
$\mathrm{B}_{1}(11.9,11.3,11.2 \& 11.1 \mathrm{~g} / 100 \mathrm{~g}$ dry $\mathrm{wt}$, respectively). That values increased to $13.2,13.4,13.5,14.4,14.8,15$ and $17.1 \mathrm{~g} / 100 \mathrm{~g}$ dry wt by the treatments of $40 \mathrm{~Gy} \mathrm{Zn}_{1}$, control $\mathrm{Zn}_{2}, 80 \mathrm{~Gy}$, control $\mathrm{Zn}_{1}$, control $\mathrm{B}_{1}$, control $\mathrm{B}_{2}$ and $40 \mathrm{~Gy}$ that considered gave the highly increased from the reducing sugars, respectively. The other treatments had reducing sugars decreased than the value of the normal seeds. Lima et al. (2011) resulted that no significant differences in content for irradiated samples $(0.5,1.0,2.5,5.0$ and $10.0 \mathrm{kGy})$. Those values increased to $13.2,13.4,13.5,14.4,14.8,15$ and $17.1 \mathrm{~g} / 100 \mathrm{~g}$ dry wt by the treatments of $40 G y \mathrm{Zn}_{1}$, control $\mathrm{Zn}_{2}, 80 \mathrm{~Gy}$ and control $\mathrm{Zn}_{1}$, control $\mathrm{B}_{1}$, control $\mathrm{B}_{2}$ and $40 \mathrm{~Gy}$ that considered gave the highly increased from the reducing sugars, respectively. The other treatments had reducing sugars decreased than the value of the normal seeds.

\section{Fatty acids}

Fatty acids of Eicosenioc, Linolenic, Linoleic and Stearic were mostly decreased in samples produced from irradiated seeds $(40,80$, and 120) and sprayed by $\left(\mathrm{Zn}_{2}\right)$ as compared by control in Table 4 . and at vice versa, Oleic, Palmitic and Myristic fatty acids were increased in irradiated samples compared with un-radiated. Margaric acid was disappeared in the control and irradiated and sprayed samples by $\mathrm{Zn}_{1}$ or $\mathrm{B}_{2}$. While it found in sample irradiated by $40 \mathrm{~Gy}$ the irradiated samples treated by $\mathrm{B}_{1}$, cause an increase in fatty acids, Palmitic and Myristic. The fatty acid of Margaric was disappeared in normal irradiated samples by 80 and $120 \mathrm{~Gy}$. Also, Stearic acid disappeared in irradiated samples by dose of $80 \mathrm{~Gy}$, and these fatty acids may be refer to transform to hydrocarbons and small portion compounds; the latest, probably degradation by $\gamma$-irradiation to $\mathrm{CO}_{2}, \mathrm{H}_{2} \mathrm{O}_{2}, \mathrm{H}_{2} \mathrm{O}$. The same trend happened when the irradiated seeds treated by $\mathrm{B}_{2}$. So, when the cowpea seeds irradiated by doses of 40,80 and 120Gy before planting, most fatty acids increased compared with control. When, the growing cowpea seeds sprayed by microelements after planting, most of fatty acids in harvested seeds increased especially with $\mathrm{Zn}_{1}$, followed by $\mathrm{Zn}_{2}$ and $\mathrm{B}_{1}$.

On the other hand, treated by $\mathrm{B}_{2}$ had destructive in the most of fatty acids. Rahimi and Bahrani (2011) results showed that the highest Canola oil percent $(48.3 \%)$ of linolenic acid and (12.7\%) of linoleic acid obtained in 100Gy and 200Gy treatment, respectively. While the lowest oil percent were (11.5\%) and $(7.6 \%)$ obtained in that of 500Gy.

Egypt. J. Rad. Sci. Applic., Vol. 24, No. 1 (2011) 
TABLE 4. Fatty acids in $V$. Sinensis as affected by $\gamma$-rays and some microelements.

\begin{tabular}{|c|c|c|c|c|c|c|c|c|}
\hline \multirow{3}{*}{ Dose/Gy } & \multicolumn{8}{|c|}{ Fatty acids } \\
\hline & $\begin{array}{c}\text { Cis-11- } \\
\text { Eicosenioc }\end{array}$ & Lionlenic & Linoleic & Oleic & Stearic & Margaric & Palmitic & Myristic \\
\hline & C 20:1 & C 18:3 & C 18:2 & C18:1 & C18:0 & C 17:0 & \begin{tabular}{|l|} 
C 16:0 \\
\end{tabular} & C 14:0 \\
\hline Con & 1.530 & 23.520 & 26.096 & 17.774 & 0.483 & 0.217 & 26.294 & 0.332 \\
\hline 40 & 1.588 & 24.200 & 26.827 & 17.129 & 0.428 & 0.205 & 25.642 & 0.298 \\
\hline 80 & 1.608 & 28.846 & 30.496 & 8.716 & 1.019 & 0.218 & 24.058 & 0.246 \\
\hline 120 & 1.898 & 27.309 & 30.342 & 9.429 & 1.451 & 0.238 & 24.056 & 0.259 \\
\hline Con $\mathrm{Zn}_{1}$ & 0.748 & 28.196 & 29.931 & 8.904 & 1.229 & 0.244 & 24.476 & 0.287 \\
\hline $40 \mathrm{Zn}_{1}$ & 1.645 & 25.974 & 28.961 & 13.217 & 1.160 & - & 25.312 & 0.308 \\
\hline $80 \mathrm{Zn}_{1}$ & 1.699 & 27.914 & 30.229 & 10.768 & 1.614 & - & \begin{tabular}{|l|}
24.077 \\
\end{tabular} & - \\
\hline $120 \mathrm{Zn}_{1}$ & 1.532 & 26.522 & 30.359 & 10.063 & 1.519 & 0.255 & 25.469 & 0.305 \\
\hline Con $\mathrm{Zn}_{2}$ & 1.875 & 26.678 & 29.498 & 10.059 & 1.323 & - & 22.725 & 0.238 \\
\hline $40 \mathrm{Zn}_{2}$ & 0.537 & 22.469 & 25.425 & 18.698 & 0.924 & 0.194 & 25.859 & 0.330 \\
\hline $80 \mathrm{Zn}_{2}$ & 1.739 & 26.916 & 28.335 & 12.574 & 0.695 & - & 24.458 & 0.269 \\
\hline $120 \mathrm{Zn}_{2}$ & 1.632 & 26.185 & 29.172 & 12.823 & 1.246 & - & 24.965 & 0.274 \\
\hline Con. $B_{1}$ & 1.863 & 28.727 & 32.157 & 7.164 & 1.374 & - & 24.514 & 0.243 \\
\hline $40 B_{1}$ & 1.739 & 23.128 & 26.093 & 17.981 & 0.861 & - & 25.226 & 0.291 \\
\hline $80 B_{1}$ & 1.545 & 27.506 & 31.956 & 9.983 & - & - & 25.105 & 0.253 \\
\hline $120 \mathrm{~B}_{1}$ & 1.541 & 26.071 & 30.108 & 11.731 & 1.109 & 0.220 & \begin{tabular}{|l|}
26.176 \\
\end{tabular} & 0.246 \\
\hline Con $B_{2}$ & 0.633 & 26.082 & 28.384 & 8.251 & 1.493 & 0.238 & 23.334 & 0.203 \\
\hline $40 B_{2}$ & 1.348 & 21.619 & 24.869 & 16.169 & 0.976 & 0.233 & 26.613 & 0.325 \\
\hline $80 B_{2}$ & 1.189 & 19.132 & 24.445 & 17.360 & 0.874 & - & 25.505 & 0.276 \\
\hline $120 \mathrm{~B}_{2}$ & 2.082 & 22.861 & 27.429 & 14.516 & 1.215 & - & \begin{tabular}{|l|}
27.307 \\
\end{tabular} & 0.359 \\
\hline
\end{tabular}

Con: control. $\quad \mathrm{Zn}_{1}: 200 \mathrm{ppm} . \quad \mathrm{Zn}_{2}: 300 \mathrm{ppm} . \mathrm{B}_{1}: 50 \mathrm{ppm} . \mathrm{B}_{2}: 100 \mathrm{ppm}$.

\section{Effect of $\gamma$-rays and some microelements on the crop parameters}

Perusal to the effect of $\gamma$-rays and micro-elements on crop parameters of cowpea, shown in Table 5, the result obtained revealed that, all treatments used improve crop productivity. It was observed that, the best cowpea quantity and quality obtained, when plants produced from seeds irradiated by 40Gy and sprayed by different concentrations of B (50 and 100ppm/ L). Growth, biochemical constituents and yield of snap bean cv. Bonco investigated by Abou El-Yazied (2011) revealed that 30 up to 80Gy produced the highest seedling emergence percentage growth, i.e., plant height, leaf number, leaf area and plant dry wt at 50 days after planting recorded significantly the highest values. And, near harvested given the highest values of pod number and pod yield per plant and Fadden and marketable yield per Fadden; also, the highest fruit set percentage. Yield per Fadden was significantly correlated with seedling

Egypt. J. Rad. Sci. Applic., Vol. 24, No. 1 (2011) 
emergence percent, seedling emergence rate, plant height, leaf number, leaf area, dry wt, fruit set, total pod number.

TABLE 5. Effect of $\gamma$-rays and microelements on crop parameters of $V$. Sinensis.

\begin{tabular}{|c|c|c|c|c|c|c|c|}
\hline \multirow[b]{2}{*}{ Dose/Gy } & \multirow{2}{*}{$\begin{array}{c}100 \\
\text { horn wt } \\
\mathrm{g}\end{array}$} & \multirow{2}{*}{$\begin{array}{c}\text { seed wt/ } \\
100 \text { horn } \\
\mathrm{g}\end{array}$} & \multirow{2}{*}{$\begin{array}{c}100 \\
\text { seed wt } \\
\quad \mathrm{g}\end{array}$} & \multicolumn{3}{|c|}{ Total crop/ Fadden } & \multirow{2}{*}{$\begin{array}{c}\text { Seed } \\
\text { shelling } \\
\%\end{array}$} \\
\hline & & & & $\begin{array}{l}\text { Horn } \\
\text { No. }\end{array}$ & $\begin{array}{c}\text { Horn wt } \\
\quad \mathrm{g}\end{array}$ & $\begin{array}{c}\text { Seed wt } \\
\mathrm{g}\end{array}$ & \\
\hline Con & $120.7^{\mathrm{g}}$ & $88.97^{\mathrm{f}}$ & $14.47^{\mathrm{e}}$ & $33552^{\mathrm{g}}$ & $41832^{\mathrm{bc}}$ & $23119.2^{\mathrm{ef}}$ & $73.73^{\mathrm{d}}$ \\
\hline 40 & $156.5^{\mathrm{ab}}$ & $121.2^{\mathrm{b}}$ & $34.9^{\mathrm{d}}$ & $64800^{\text {cd }}$ & $97149.6^{\mathrm{bc}}$ & $33652.8^{\text {ef }}$ & $774^{\mathrm{cd} d}$ \\
\hline 80 & $120.8^{\mathrm{f}}$ & $89.1^{\mathrm{f}}$ & $15.88^{\mathrm{e}}$ & $44352^{\text {efg }}$ & $55886.4^{\mathrm{bc}}$ & $28490.4^{\text {ef }}$ & $76.81^{\text {cd }}$ \\
\hline 120 & $121.3^{\mathrm{f}}$ & $91.8^{\mathrm{ef}}$ & $15.47^{\mathrm{e}}$ & $37656^{\mathrm{fg}}$ & $29332.8^{\mathrm{c}}$ & $24343.6^{\mathrm{ef}}$ & $75.68^{\mathrm{d}}$ \\
\hline Con $\mathrm{Zn}_{1}$ & $142.9^{\mathrm{c}}$ & $111.2^{\mathrm{c}}$ & $15.2^{\mathrm{e}}$ & $38232^{\mathrm{fg}}$ & $52696.8^{\mathrm{bc}}$ & $28562.4^{\mathrm{ef}}$ & $77.82^{\mathrm{cd}}$ \\
\hline $40 \mathrm{Zn}_{1}$ & $155.2^{\mathrm{ab}}$ & $122.1^{b}$ & $54.02^{b}$ & $75072^{\mathrm{bc}}$ & $99856.4^{\mathrm{a}}$ & $81385.6^{\mathrm{d}}$ & $81.50^{c}$ \\
\hline $80 \mathbf{Z n}_{1}$ & $122.2^{f}$ & $89.67^{\mathrm{t}}$ & $14.7^{\mathrm{e}}$ & $60192^{\text {cde }}$ & $48585.6^{\mathrm{bc}}$ & $26820^{\text {ef }}$ & $75.02^{\mathrm{d}}$ \\
\hline $120 \mathrm{Zn}_{1}$ & $120.3^{\mathrm{f}}$ & $93.5^{\mathrm{ef}}$ & $15.27^{\mathrm{e}}$ & $34848^{\mathrm{g}}$ & $35712^{\mathrm{bc}}$ & $20728.8^{\mathrm{ef}}$ & $73.28^{\mathrm{d}}$ \\
\hline $\operatorname{Con} \mathrm{Zn}_{2}$ & $121.7^{\mathrm{f}}$ & 91.3 & $14.87^{\mathrm{e}}$ & $29304^{\mathrm{g}}$ & $39352.2^{\mathrm{bc}}$ & $22932^{\mathrm{ef}}$ & $76.92^{\text {cd }}$ \\
\hline $40 \mathrm{Zn}_{2}$ & $133.3^{\mathrm{e}}$ & $125^{\mathrm{b}}$ & $43.73^{\mathrm{c}}$ & $82672^{\text {ab }}$ & $225207^{\mathrm{abc}}$ & $198768^{c}$ & $88.26^{\mathrm{b}}$ \\
\hline $80 \mathrm{Zn}_{2}$ & $140.23^{\text {cd }}$ & $99.9^{\mathrm{de}}$ & $14.5^{\mathrm{e}}$ & $57312^{\text {cde }}$ & $69588^{\mathrm{bc}}$ & $40903.2^{\mathrm{e}}$ & $76.22^{\mathrm{cd}}$ \\
\hline $120 \mathrm{Zn}_{2}$ & $125.8^{\mathrm{f}}$ & $96.1^{f}$ & $14.72^{\mathrm{e}}$ & $66384^{\text {bcd }}$ & $67075.2^{\mathrm{bc}}$ & $40838.4^{\mathrm{e}}$ & $74.35^{\mathrm{d}}$ \\
\hline Con. $B_{1}$ & $122.8^{\mathrm{f}}$ & $89.76^{\mathrm{det}}$ & $16.1^{\mathrm{e}}$ & $62424^{\text {cd }}$ & $72648^{\mathrm{bc}}$ & $40579.2^{\mathrm{e}}$ & $74.70^{\mathrm{d}}$ \\
\hline $40 B_{1}$ & $158.7^{\mathrm{a}}$ & $119.5^{\mathrm{b}}$ & $58.9^{b}$ & $90328^{\mathrm{a}}$ & $267982^{\mathrm{ab}}$ & $241594^{b}$ & $90.15^{\mathrm{ab}}$ \\
\hline $80 \mathrm{~B}_{1}$ & $123.4^{\mathrm{f}}$ & $053^{\mathrm{e}}$ & $15.7^{\mathrm{e}}$ & $34776^{\mathrm{g}}$ & $47131.2^{\mathrm{bc}}$ & $23025.6^{\mathrm{ef}}$ & $77.23^{\mathrm{cd}}$ \\
\hline $120 B_{1}$ & $151.1^{\mathrm{b}}$ & $93.95^{\mathrm{ef}}$ & $14.88^{\mathrm{e}}$ & $1507^{\mathrm{h}}$ & $23401^{\mathrm{c}}$ & $10231^{\mathrm{f}}$ & $62.18^{\mathrm{e}}$ \\
\hline Con $B_{2}$ & $121.3^{\mathrm{f}}$ & $93.83^{\text {ef }}$ & $15.5^{\mathrm{e}}$ & $33048^{\mathrm{g}}$ & $40240.8^{\mathrm{bc}}$ & $22744.8^{\mathrm{ef}}$ & $75.32^{\mathrm{d}}$ \\
\hline $40 B_{2}$ & $157.4^{\mathrm{ab}}$ & $139.9^{\mathrm{a}}$ & $98.5^{\mathrm{a}}$ & $92980^{\mathrm{a}}$ & $370927^{\mathrm{a}}$ & $346951^{\mathrm{a}}$ & $93.54^{\mathrm{a}}$ \\
\hline $80 B_{2}$ & $123.6^{\mathrm{t}}$ & $97.03^{\mathrm{def}}$ & $16.13^{\mathrm{e}}$ & $32976^{\mathrm{g}}$ & $37706.4^{\mathrm{bc}}$ & $22255.2^{\mathrm{ef}}$ & $74.35^{\mathrm{d}}$ \\
\hline $120 \mathrm{~B}_{2}$ & $135.5^{\text {de }}$ & $103.6^{\mathrm{d}}$ & $14.58^{\mathrm{e}}$ & $54720^{\text {def }}$ & $67132.8^{\mathrm{bc}}$ & $15192^{\mathrm{f}}$ & $76.42^{\text {cd }}$ \\
\hline L.S.D ${ }_{0.05}$ & 6.383 & 7.147 & 6.052 & 16322.4 & 195176.4 & 20624.2 & 4.787 \\
\hline
\end{tabular}

Con: control. $\mathrm{Zn}_{1}: 200 \mathrm{ppm} . \mathrm{Zn}_{2}: 300 \mathrm{ppm} . \mathrm{B}_{1}: 50 \mathrm{ppm} . \mathrm{B}_{2}: 100 \mathrm{ppm}$.

Generally, $\gamma$-rays of 40, 80 and 120Gy doses increased the cowpea crop qualitatively and quantitatively when seeds exposed to $\gamma$-radiation before planting, especially with dose of 40Gy that improved most physical, chemical and yields parameters. That dose (40Gy) caused a characteristics enhancement when the irradiated seeds sprayed with micro elements of $\mathrm{B}_{1}, \mathrm{~B}_{2}, \mathrm{Zn}_{1}$ and $\mathrm{Zn}_{2}$ after one month of planting. Thus, it can be classified the effect of the agrochemical foliar sprays and $\gamma$-rays used on cowpea for increasing crop quality and quantity as follows: the dose 40Gy either sprayed by $\mathrm{Zn}$ or $\mathrm{Br}$ gained the highest growth and yield parameters and chemical composition followed by $80 \mathrm{~Gy}$ sprayed or not and the last one was $120 \mathrm{~Gy}$. The increase in 
crop parameters might be due to the fulfillment of $\mathrm{Zn}$ or B deficiency. Similar findings were obtained by Mehmood et al. (2009).

\section{Acknowledgment}

Meaning participated the work raved the deceased Dr. Mohammed Ibrahim Abdullah gives us good example devotion in the work; optimistically performer, work ethics and continue immortal our hearts.

\section{References}

Abdul Majeed, A., Khan, R., Ahmad, H. and Muhammad, Z. (2010) Gamma irradiation effects on some growth parameters of Lepidium sativum L. ARPN J. Agricul. Biol. Sci., 5, 39 .

Abou El-Yazied, A. (2011) Growth, biochemical constituents and yield of snap bean as influenced by low gamma irradiation doses under different sowing dates. Aust. J. Basic Appl. Sci., 5, 30.

AOAC (1995) Official method of analysis of Association of Official Agriculture Chemists. $16^{\text {th }}$ ed, Washington D.C. USA.

AOAC (2000) Official methods of analysis of the Association of Official Analytical Chemist. $14^{\text {th }} \mathrm{cd}$ Washington, D.C. USA.

AOAS (1984) Official and tentative methods. $3^{\text {rd }}$ ed, American Oil Chemist's Society, Champaign, IL.

Chakravarty, B. and Sen, S. (2001) Enhancement of regeneration potential and variability by $\beta$-irradiation in cultured cells of Scilla indica. Biol. Plant, 44, 189.

Ciesta, K., Roos Y. and Ciluszewski, W. (2000) Denaturation process in gamma irradiated protein studied by differential scanning colorimetry. Rad. Phys. Chem., 58, 233.

Duncan, D. B. (1955) Multiple ranges and multiple F. test. Biomerics. 11, 1.

Goldbach, H. E., Yu. Q., Wingender, R., Schulz, M., Wimmer, M., Findeklee, P. and Baluka, F. (2001) Rapid response reactions of roots to boron deprivation. J. Plant Nut. Soil. Sci. 164, 173.

Hassan, H. M., Ali, M. A. and Darwish, I. M. (2000) Effect of gamma irradiation on the susceptibility of cowpea to root-knot nematode (Meloidogyne incognita). Minia . J. Agric. Res. Develop., 20, 47.

Hosfield, G. L., Sippel, S. A. and Curtin, D. D. (1982) A direct and analytical method for determining water-soluble sugar from a single extract of carrot root tissue. J. Amer. Soc. Hort. Sci., 107, 101.

Hussein, O. S. (2008) Effect of presowing soaking treatments on growth and yield of irradiated Cicer arietinum seeds. J. Rad. Appl. Sci. 1, 79.

Egypt. J. Rad. Sci. Applic., Vol. 24, No. 1 (2011) 
Joesph, O. (2006) Amino acid composition of cowpea water and salt extractable proteins as affected by high dose gamma radiation. Nigerian Food J., 13.

Kassem, H. A., Marzouk, H. A., Ei-kobbia, A. and Abu-Elmagd, M. (2011) Influence of different agrochemicals foliar sprays on post-harvest fruit quality of Navel orange. Emir. J. Food Agric., 23, 187.

Lima, K. S. C., Souza, L. B., Godoy, R. L. O., France, T. C. C. and Lima, A. L. S. (2011) Effect of gamma irradiation and cooking on cowoea bean grains (vigna unguiculata L.Walp). Rad. Phy. Chem., 80, 983.

Loomis, W. D. and Durst, R. W. (1992) Chemistry and biology of boron. Biofactors, 3, 229

Lukaszewski, K. M. and Blevins, D. G. (1996) Root growth inhibition in boron deficient and aluminum stressed squash may be a result of impaired ascorbate metabolism. Plant Physiol., 112, 1235.

Marschner, H. (1995) Nutritional physiology. In: Mineral nutrition of higher plants, 2nd edn. Academic Press, San Diego, pp 379.

Mehmood, E. Ul-H., Kausar, R., Akram, M. and Shahzad, S. M. (2009) Is boron required to improve rice growth and yield in saline environment. Pak. J. Bot., 41, 1339.

Nassar, A. H., Hashim, M. F., Hassan, N. S. and Abo-Zaid, H. (2004) Effect of gamma irradiation and phosphorus on growth and oil production of chamomile (Chamomilla recutita L. Rauschert). Int. J. Agri. Biol., 6, 776.

Orabi, O. A. I. (1998) Effect of seed irradiation and salinity on growth, chemical composition, flowering and seed production and its quality of Cowpea. Egypt. J. Appl. Sci., 13, 201.

Panjie, R. R. And Jagadees, P. P. R. (1959) The effect of ionizing radiation on sugarcane. In: Proc. Int. Soc. Sugarcane Tech., $10^{\text {th }}, 775$.

Prabhu, I. and Muthuchelian, K. (2011) Photoinhibition of Photosynthesis in Leaves of Cowpea (Vigna unguiculata L. Walp. P152) in Response to Zinc and High Irradiance Stresses. World Appl. Sci. J., 15, 1334.

Rahimi, M. M. and Bahrani, A. (2011) Effect of gamma irradiation on qualitative and quantitative characteristics of Canola (Brassica napus L.). Middil. East J. Sci. Res., 8, 519.

Ribeiro, R. V. and Machado, E. C. (2007) Some aspects of Citrus ecophysiology in subtropical climates: Revisiting photosynthesis under natural conditions. Braz. J. Physiol., 19, 393.

Shannon, J. C. (1968) A procedure for the extraction and fractionation of carbohydrates from immature Zea Mays kernels. Purdue Agric. Expt. Sta. Res. Bull., 842. 
Smith, F., Gilles, M. A., Hamilton, J. K., Rebers, P. A. and Dubios, M. (1956) Colorimetric method of determination of sugars and related substances. Anal. Chem., 28, 350.

Thomas, D. J. and Atwell, W. A. (1997) Starches. Eagan Press handbook series St. Paul, Minnesota, USA: American Association of Cereal Chemists.

Vasconcelos, I. M., Machado, F. M., Farias, D. F., Campello, C. C., Carvalho, A. F., Moreira, R. A. and Oliveira, J. T. (2010) Protein fractions, amino acid composition and antinutritional constituents of high-yielding cowpea cultivars. J. Food Composit. Analy., 23, 54.

Vogel, A. J. (1975) A text book of practical organic chemistry. English Language Book Society and Longman Group Ltd. London. $3^{\text {rd }}$ ed., 969.

(Received: 09/10/2011;

accepted: 28/12/2011)

Egypt. J. Rad. Sci. Applic., Vol. 24, No. 1 (2011) 


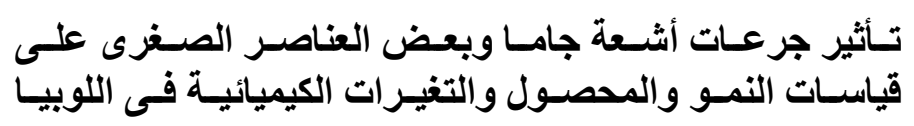

Vigna sinensis $L$.

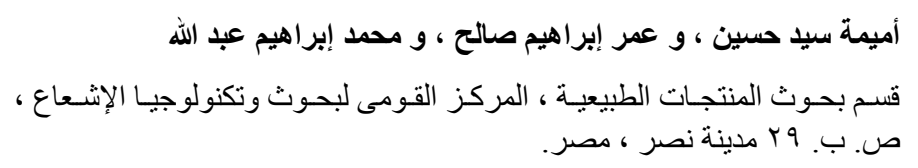

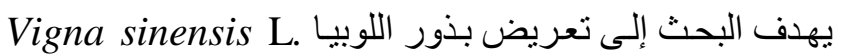

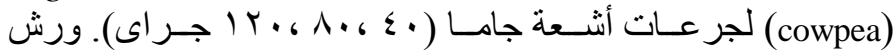

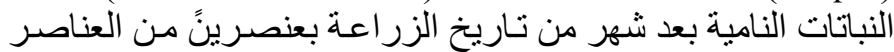

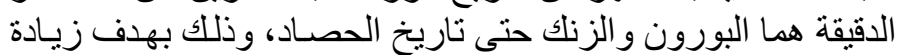

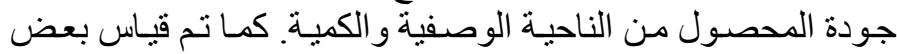

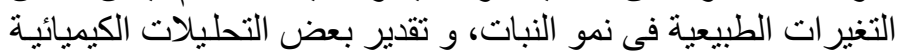

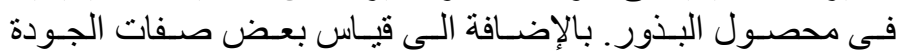

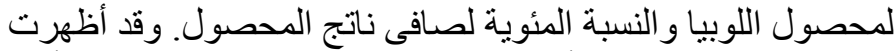

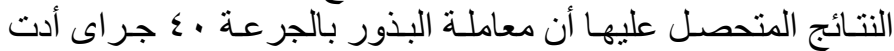

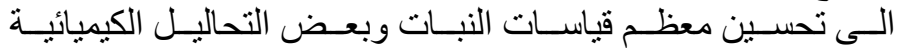

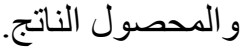

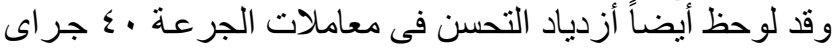

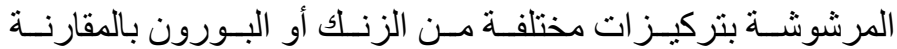

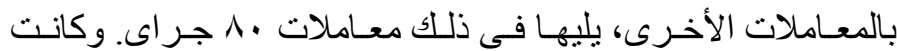

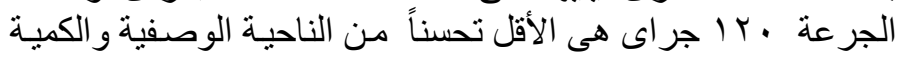

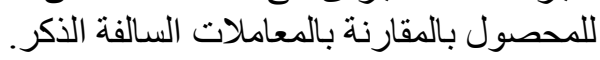

